7. Reprod. Fert. (1969) 19, 95-102

\title{
QUANTITATIVE ANALYSIS OF PORCINE SPERMATOZOA AND SEMINAL PLASMA PHOSPHOLIPIDS AS AFFECTED BY FREQUENCY OF EJACULATION
}

\author{
L. A. JOHNSON, R. J. GERRITS and E. P. YOUNG \\ Animal Husbandry Research Division, U.S. Department of Agriculture, Beltsville, \\ Maryland, and Department of Animal Science, University of Maryland, College Park, \\ Maryland, U.S.A.
}

(Received 27th May 1968, accepted 27th Fuly 1968)

\begin{abstract}
Summary. Sixty-four ejaculates were collected from four crossbred litter-mate boars. Two frequencies of ejaculation were employed; once every 3 days and daily. Total semen volume $(\mathrm{ml})$ and total spermatozoa per ejaculate $\left(\times 10^{9}\right)$ for the two frequencies were $157,37 \cdot 4$; and $131 \cdot 9$, $19 \cdot 7$, respectively. Spermatozoa and seminal plasma phospholipids were determined by thin-layer chromatography and phosphorus analysis. The phospholipid components of spermatozoa, in order of decreasing concentration, were: choline phosphatides, ethanolamine phosphatides, sphingomyelin, serine phosphatides, phosphatidic acid and/or polyglycerol phosphatides. Differences between collection frequencies for the phospholipid components were not significant. The seminal plasma phospholipid contained the same component phospholipids as the spermatozoa in addition to trace quantities of lysolecithin. Sphingomyelin was the major phospholipid present in the seminal plasma.
\end{abstract}

\section{INTRODUCTION}

The lipid composition of semen from various species has been the object of intensive investigation. Lecithin and choline plasmalogen were the major phospholipids observed in ram semen (Lovern, Olley, Hartree \& Mann, 1957; Hartree \& Mann, 1959, 1960, 1961; Gray, 1960; Quinn \& White, 1967). Bovine semen contained up to seven classes of lipid of which 60 to $74 \%$ was phospholipid (Miller \& Mayer, 1965; Komarek, Pickett, Lanz \& Jensen, 1964; Pursel \& Graham, 1967). Komarek, Pickett, Gibson \& Jensen (1965) reported that boar semen contained five classes of lipids: phospholipid, cholesterol, triglycerides, diglycerides and wax esters. Five phospholipids were reported in freeze-dried boar spermatozoa by Grogan, Mayer \& Sikes (1966). They were phosphatidyl choline, phosphatidyl ethanolamine, choline plasmalogen, ethanolamine plasmalogen, and sphingomyelin.

The objectives of the present investigation were to separate and quantify the 
phospholipids of boar spermatozoa and seminal plasma and to determine the influence of ejaculation frequency on these constituents.

\section{MATERIALS AND METHODS}

\section{Collection and handling of semen}

The semen was collected from four crossbred littermate boars at 14 months of age. The boars were randomly assigned to either of two ejaculation frequencies. Semen collections were made four times in 12 days at 72 -hr intervals from one pair while collections were made daily for 12 days at $24-\mathrm{hr}$ intervals from the other pair. At the end of the 12-day collection period, a 15-day recovery period was allowed in which four ejaculates were collected from all boars. After the recovery period, the pairs were reversed and assigned to the opposite ejaculation frequency. Recovery period ejaculates were not retained for chemical analysis.

The boars were trained to mount a 'dummy sow' and serve an artificial vagina. The semen was collected directly into a beaker, the top of which was covered with gauze. The technique effectively separated the gel particles from the semen. The temperature of the semen was maintained at $37^{\circ} \mathrm{C}$ during collection by a water jacket around the beaker. Motility was determined under a light microscope at $\times 100$ magnification. Abnormal spermatozoa were counted at $\times 430$ magnification. Sperm cell concentration was determined by taking the average of four haemocytometer counts. Dry weight determinations were made according to the method of Komarek et al. (1964).

Within $1 \mathrm{hr}$ of collection, the semen was separated into spermatozoa and plasma by centrifugation at $30,000 \mathrm{~g}$ for $20 \mathrm{~min}$. The spermatozoa were stored in liquid nitrogen $\left(-196^{\circ} \mathrm{C}\right)$ and the seminal plasma at $-20^{\circ} \mathrm{C}$. The seminal plasma was freeze-dried before extraction of the lipid. Analysis of the spermatozoa was accomplished after pooling ejaculates 1 to 3,4 to 6,7 to 9 and 10 to 12 on the daily interval to give four samples per boar; whereas the ejaculates from each boar on the 3-day interval were analysed without pooling. Before freeze-drying, the seminal plasma from the daily interval ejaculates was pooled by Days 1 to 6 and 7 to 12 to give two samples per boar. On the 3-day collection interval the plasma from the four ejaculates was pooled to make one sample per boar.

\section{Lipid extraction}

The lipids were extracted and purified at room temperature with chloroform: methanol $(2: 1 \mathrm{v} / \mathrm{v})$ according to the method of Folch, Lees \& Sloane-Stanley (1957). Freeze-dried seminal plasma was diluted with water $(2 \mathrm{ml} / \mathrm{g}$ of freezedried plasma) before extraction. Total lipid was determined gravimetrically.

\section{Chromatography and phosphorus analysis}

Thin-layer chromatography employing silica gel $\mathrm{H}$ was used to separate the phospholipids. A solvent system of chloroform:methanol:acetic acid:water $(25: 15: 4: 2 \mathrm{v} / \mathrm{v} / \mathrm{v} / \mathrm{v})$ was employed (Skipski, Peterson \& Barclay, 1964). Identification of phospholipid fractions was made by co-chromatography with 
pure phospholipid standards (Applied Science Laboratories, State College, Pennsylvania). Detection procedures described by Skidmore \& Entenman (1962) were also used to help in identification.

Duplicate applications of spermatozoa and seminal plasma lipid in chloroform were made to the thin-layer with a microsyringe. Ten to $12 \mu \mathrm{g}$ of phosphorus were applied from the sperm extract and 4 to $5 \mu \mathrm{g}$ from the seminal plasma extract. Developing time was 75 to $90 \mathrm{~min}$. The plates were air dried and exposed to iodine vapour after development. The spots were immediately outlined with a sharp probe. After the iodine evaporated, the outlined areas were recovered and transferred to $15-\mathrm{ml}$ centrifuge tubes. Blank areas were recovered similarly. The phospholipid was extracted from the silica gel with $1 \mathrm{~N}-$ methanolic hydrochloric acid according to DeBohner, Soto \& DeCohan (1965). Phosphorus was determined in the concentrated extract by the method of Bartlett (1959). Absorbance was determined at $830 \mathrm{~m} \mu$ with a Beckman Model B Spectrophotometer using silica cells and red sensitive phototube. Arc-sine transformation was applied to all percentages before statistical analysis. Data were analysed by least squares analysis of variance.

\section{RESULTS}

Some of the characteristics of the semen representing sixty-four ejaculates and dry weight values are presented in Table 1 . Liquid semen volume was reduced,

\section{TABLE 1}

SEMEN CHARACTERISTICS AND DRY WEYGHT OF SEMEN FROM BOARS EJACULATED AT 1 - AND 3-DAY INTERVALS

\begin{tabular}{|c|c|c|}
\hline & \multicolumn{2}{|c|}{ Interval of collection } \\
\hline & $1-d a y^{*}$ & 3-day $\dagger$ \\
\hline $\begin{array}{l}\text { Gel volume }(\mathrm{ml}) \\
\text { Liquid volume }(\mathrm{ml}) \\
\text { Total volume }(\mathrm{ml}) \\
\text { Spermatozoa } / \mathrm{ml}\left(\times 10^{6}\right) \\
\text { Total spermatozoa } / \text { ejac. }\left(\times 10^{9}\right) \\
\text { Spermatozoa per day }\left(\times 10^{9}\right) \\
\text { Abnormalities }(\%) \\
\text { pH }\end{array}$ & $\begin{array}{r}21 \cdot 5 \\
110 \cdot 5 \\
131 \cdot 9 \\
176 \cdot 8 \\
19 \cdot 7 \\
19 \cdot 7 \\
9 \cdot 8 \\
7 \cdot 78\end{array}$ & $\begin{array}{l}23 \cdot 8 \\
133 \cdot 3 \\
157 \cdot 0 \\
298 \cdot 9^{* *} \\
37 \cdot 4^{* *} \\
12 \cdot 9 \\
10 \cdot 1 \\
7 \cdot 69\end{array}$ \\
\hline $\begin{array}{l}\text { Dry weights: } \\
\text { Whole semen }(\mathrm{g} / 100 \mathrm{~g}) \\
\text { Seminal plasma }(\mathrm{g} / 100 \mathrm{~g}) \\
\text { Spermatozoa }\left(\mathrm{mg} / 10^{9} \text { spermatozoa }\right)\end{array}$ & $\begin{array}{r}3 \cdot 46 \\
3 \cdot 07 \\
25 \cdot 22\end{array}$ & $\begin{array}{l}4 \cdot 37 * * \\
3 \cdot 63 \\
22 \cdot 91\end{array}$ \\
\hline
\end{tabular}

* Mean values representing forty-eight ejaculates.

$\dagger$ Mean values representing sixteen ejaculates.

** $P<0.01$.

though not significantly, when the collection was made daily. Gel volume was not measurably affected by the more frequent collection interval.

Sperm production per ejaculate was significantly $(P<0.01)$ reduced for the boars collected at the daily interval. Total spermatozoa production for the 12-day period was $35 \%$ greater when the collection was made daily than when 
made every 3 days. The daily pattern of sperm cell production and semen volume is shown in Table 2. The effect of daily collection is apparent in both measurements.

\section{TABLE 2}

SPERM GELL PRODUCTION AND SEMEN VOLUME PATTERN OF BOARS EJACULATED AT 1- AND 3-DAY INTERVALS

\begin{tabular}{|c|c|c|c|c|}
\hline \multirow{2}{*}{$\begin{array}{c}\text { Day of } \\
\text { collection }\end{array}$} & \multicolumn{2}{|c|}{$\begin{array}{c}\text { Spermatozoa produc- } \\
\text { tion }^{*}\left(\times 10^{9}\right)\end{array}$} & \multicolumn{2}{|c|}{$\begin{array}{c}\text { Total semen } \\
\text { polume* }(\mathrm{ml})\end{array}$} \\
\hline & $\begin{array}{l}\text { 1-day } \\
\text { interval }\end{array}$ & $\begin{array}{l}\text { 3-day } \\
\text { interval }\end{array}$ & $\begin{array}{l}\text { 1-day } \\
\text { interval }\end{array}$ & $\begin{array}{l}\text { 3-day } \\
\text { interval }\end{array}$ \\
\hline 1 & $48 \cdot 51$ & - & 182 & - \\
\hline 2 & $25 \cdot 76$ & $40 \cdot 52$ & 146 & 159 \\
\hline 3 & $23 \cdot 41$ & - & 120 & - \\
\hline 4 & $21 \cdot 42$ & - & 137 & - \\
\hline 5 & 15.56 & $40 \cdot 75$ & 122 & 168 \\
\hline 6 & $9 \cdot 59$ & - & 130 & - \\
\hline 7 & $17 \cdot 60$ & - & 133 & - \\
\hline 8 & $13 \cdot 76$ & $26 \cdot 30$ & 123 & 155 \\
\hline 9 & $16 \cdot 20$ & - & 124 & - \\
\hline 10 & 11.92 & - & 121 & - \\
\hline 11 & $15 \cdot 81$ & $42 \cdot 41$ & 116 & 145 \\
\hline 12 & $17 \cdot 25$ & - & 125 & - \\
\hline
\end{tabular}

TABle 3

LIPID COMPOSITION OF BOAR SPERMATOZOA AND SEMINAL PLASMA GOLLECTED AT 1- AND 3-DAY INTERVALS

\begin{tabular}{|c|c|c|c|c|}
\hline & \multicolumn{2}{|c|}{ Spermatozoa } & \multicolumn{2}{|c|}{ Seminal plasma } \\
\hline & $\begin{array}{l}\text { 1-day* } \\
\text { interval }\end{array}$ & $\begin{array}{l}3-d a y \dagger \\
\text { interval }\end{array}$ & $\begin{array}{l}\text { 1-day* } \\
\text { interval }\end{array}$ & $\begin{array}{l}\text { 3-day† } \\
\text { interval }\end{array}$ \\
\hline $\begin{array}{l}\text { Total lipid (g/100 g dry matter) } \\
\text { Total lipid }\left(\mathrm{mg} / 10^{9} \text { spermatozoa) }\right. \\
\text { Total lipid }(\mu \mathrm{g} / \mathrm{ml})\end{array}$ & $\begin{array}{r}10 \cdot 36 \\
2 \cdot 60 \\
-\end{array}$ & $\begin{array}{r}11 \cdot 58 \\
2 \cdot 64 \\
-\end{array}$ & $\begin{array}{r}0 \cdot 15 \\
47 \cdot 23\end{array}$ & $\frac{0 \cdot 17}{61 \cdot 37}$ \\
\hline $\begin{array}{l}\text { Phospholipid (\% of total lipid) } \\
\text { Lipid phosphorus }\left(\mu \mathrm{g} / 10^{9} \text { spermatozoa) }\right. \\
\text { Lipid phosphorus }(\mu \mathrm{g} / \mathrm{ml})\end{array}$ & $\begin{array}{c}70 \cdot 09 \\
73 \cdot 00 \\
-\end{array}$ & $\begin{array}{c}68 \cdot 00 \\
71 \cdot 55 \\
-\end{array}$ & $\frac{40 \cdot 86}{0 \cdot 76}$ & $\frac{43 \cdot 92}{1 \cdot 03^{* *}}$ \\
\hline $\begin{array}{l}\text { Phospholipid (mg/109 spermatozoa) } \\
\text { Phospholipid }(\mu \mathrm{g} / \mathrm{ml})\end{array}$ & $1 \cdot 81$ & $1 \cdot 79$ & $\overline{18 \cdot 52}$ & $25 \cdot \overline{62 * *}$ \\
\hline
\end{tabular}

Phospholipid was calculated by phosphorus $\times 25$.

* Mean values representing forty-eight ejaculates.

$\dagger$ Mean values representing sixteen ejaculates.

** $P<0.05$.

Lipid composition values for boar spermatozoa and seminal plasma are presented in Table 3. Total lipid was calculated on the basis of dry matter. The seminal plasma was very low in total lipid compared to the sperm cell. Lipid calculated relative to spermatozoa showed 2.60 and $2.64 \mathrm{mg} / 10^{9}$ spermatozoa for 1- and 3-day intervals, respectively. Phospholipid represented 70.1 and 
$68.0 \%$ of the total lipid in the spermatozoa for the 1- and 3-day intervals, respectively. Seminal plasma phospholipid was considerably lower, 40.9 and $43.9 \%$ for the 1- and 3-day intervals, respectively. Phospholipid $/ \mathrm{ml}$ of seminal plasma was reduced significantly $(P<0.05)$ for the daily interval of collection (18.52 and $25.62 \mu \mathrm{g} / \mathrm{ml})$.

Component phospholipid values for spermatozoa and seminal plasma are presented in Table 4. The choline phosphatides were the major phospholipid component present in spermatozoa, while sphingomyelin was predominant in seminal plasma phospholipid. The spermatozoa and seminal plasma differed also in that lysolecithin was absent in the spermatozoa but present in the seminal plasma, though as a minor component. The major components of the sperm cell phospholipids were choline phosphatides ( 41 to $44 \%$ ), ethanolamine

TABLE 4

COM PONENT PHOSPHOLIPIDS OF BOAR SPERMATOZOA AND SEMINAL PLASMA COLLEGTED AT 1 - AND 3-DAY INTERVALS

\begin{tabular}{|c|c|c|c|c|}
\hline & \multicolumn{2}{|c|}{ Spermatozoa } & \multicolumn{2}{|c|}{ Seminal plasma } \\
\hline & $\begin{array}{l}\text { 1-day* } \\
\text { interval }\end{array}$ & $\begin{array}{l}\text { 3-day } \dagger \\
\text { interval }\end{array}$ & $\begin{array}{l}\text { 1-day** } \\
\text { interval }\end{array}$ & $\begin{array}{l}\text { 3-day } \dagger \\
\text { interval }\end{array}$ \\
\hline $\begin{array}{l}\text { Choline phosphatides } \\
\text { Ethanolamine phosphatides } \\
\text { Serine phosphatides } \\
\text { Sphingomyelin } \\
\text { Lysolecithin } \\
\text { Phosphatidic acid and/or } \\
\text { polyglycerol phosphatides }\end{array}$ & $\begin{array}{c}41 \cdot 44 \ddagger \\
25 \cdot 98 \\
5 \cdot 90 \\
15 \cdot 15 \\
- \\
5 \cdot 52\end{array}$ & $\begin{array}{r}43 \cdot 56 \\
25 \cdot 64 \\
5 \cdot 43 \\
15 \cdot 78 \\
- \\
5 \cdot 18\end{array}$ & $\begin{array}{r}10 \cdot 52 \\
29 \cdot 95 \\
12 \cdot 74 \\
32 \cdot 55 \\
1 \cdot 11 \\
5 \cdot 55\end{array}$ & $\begin{array}{r}10 \cdot 91 \\
29 \cdot 81 \\
12 \cdot 96 \\
34 \cdot 93 \\
1 \cdot 44 \\
5 \cdot 61\end{array}$ \\
\hline Non-migrating phospholipid & $6 \cdot 00 * *$ & 4.48 & $7 \cdot 47$ & $4 \cdot 96$ \\
\hline
\end{tabular}

* Mean values representing forty-eight ejaculates.

$\dagger$ Mean values representing sixteen ejaculates.

$\neq$ Per cent of total phospholipid.

$* * P<0.01$.

phosphatides (25 to $26 \%$ ) and sphingomyelin (15 to $16 \%$ ). Ethanolamine phosphatide composition was significantly different $(P<0.05)$ among boars.

There were no significant differences between collection intervals in the component phospholipids of the seminal plasma. Ethanolamine phosphatides (29 to $30 \%$ ) and serine phosphatides (12 to $13 \%$ ) in addition to the major component, sphingomyelin ( 32 to $35 \%$ ), comprised the majority of seminal plasma phospholipid.

Phosphatidic acid and/or polyglycerol phosphatides in spermatozoa and seminal plasma represented just over $5 \%$ of the total phospholipid and differed significantly $(P<0.05)$ among boars but not between collection intervals. Phospholipid remaining at the origin was labelled non-migrating phospholipid and was quite variable, representing 4 to $7 \%$ of the total phospholipid. The non-migrating phospholipid was probably composed of a little of each of the phospholipid fractions since it gave a positive reaction for choline and amino groups. Recovery rate of phosphorus from the thin-layer plates averaged $93.0 \%$ for the spermatozoa lipid analyses and $97.8 \%$ for the seminal plasma. After 
termination of the experiment, all boars were mated by natural service and exhibited normal fertility.

\section{DISGUSSION}

Total ejaculate volume was somewhat lower than that generally reported for adult boars (McKenzie, Miller \& Baugness, 1938; Radford, 1961; Mann, 1964). Total sperm production over the 12-day period of the present study was higher for daily semen collections than for those made at 3-day intervals. Sperm production per ejaculate was significantly reduced on the daily interval which is in agreement with the reports of Gerrits, Graham \& Cole (1962) and Kaplan (1966).

Whole semen dry weight was significantly $(P<0.01)$ greater for boars ejaculated on the 3-day interval compared to the daily collection interval. Seminal plasma dry weight differed significantly $(P<0.05)$ among boars but not between collection intervals. The 3-day collection values were similar to those reported by Komarek et al. (1965) and Pickett, Komarek, Gebauer \& Gibson (1967). Sperm cell total lipid values were similar to those reported by Komarek et al. (1965) and Pickett et al. (1967). The seminal plasma was quite low in total lipid $(0 \cdot 17$ and $0 \cdot 15 \%)$. These values are generally lower than the $0.29 \%$ reported by Komarek et al. (1965) and the $0.36 \%$ reported by Pickett et al. (1967). One factor which could have contributed to these differences was that different extraction techniques were used in all three studies. The difficulty regarding extraction of boar seminal plasma lies in its large volumes and low lipid content. Although not significant, there was an inverse relationship between seminal plasma lipid per $\mathrm{ml}$ and sperm concentration per $\mathrm{ml}$.

Phospholipid as a percentage of sperm total lipid was nearly the same for the two collection intervals and was, in general, in agreement with that reported by Komarek et al. (1965). Phospholipid as a percentage of seminal plasma total lipid was considerably lower than was true for the spermatozoa. The values (40 to $44 \%$ ) were much lower than the $64.7 \%$ reported by Komarek et al. (1965) for seminal plasma lipid. The source of this discrepancy may well have been the fact that Komarek's study employed gravimetric techniques to determine various classes of lipid. Hence, there was a possible inclusion of non-phosphorus containing compounds. Our study employed direct phosphorus analysis. Phospholipid per $\mathrm{ml}$ of seminal plasma was significantly $(P<0.05)$ higher for the boars on the 3-day interval compared to the daily interval. No explanation can be offered for this difference at the present time. In contrast, phospholipid/ $10^{9}$ spermatozoa did not differ significantly between intervals of collection.

Freeze-dried boar spermatozoa were reported to contain phosphatidyl choline, phosphatidyl ethanolamine, choline plasmalogen, ethanolamine plasmalogen and sphingomyelin by Grogan et al. (1966). In the study reported here, component phospholipids were determined using thin-layer chromatography in a solvent system carrying cholesterol and neutral lipids at the solvent front. Plasmalogens were not determined individually but are present in boar spermatozoa (Grogan et al., 1966) and in this solvent system migrate with the fraction whose base moiety they contain. 
The choline phosphatides were the predominant phospholipids present in the spermatozoa as indeed they are in the spermatozoa and body tissues of various other species (Gray, 1960; Dawson, Hemington \& Lindsay, 1960; DeGier \& Van Deenen, 1961; Pursel \& Graham, 1967). The choline phosphatide composition was somewhat lower than the $48.1 \%$ (choline plasmalogen and phosphatidyl choline) reported by Grogan et al. (1966). Seminal plasma choline phosphatides were dramatically different, constituting only $10 \%$ of the total phospholipid. In contrast to spermatozoa, sphingomyelin was the predominant phospholipid ( 32 to $35 \%$ ) in seminal plasma. Spermatozoa and seminal plasma contained ethanolamine phosphatides in similar amounts (25 and $29 \%$, respectively). Serine phosphatide concentrations in seminal plasma were more than twice those present in the spermatozoa.

In conclusion, there was very little effect of increased frequency of ejaculation on the phospholipid composition of the spermatozoa and seminal plasma of the boar. This, coupled with the fact that boars ejaculating daily for 12 days produced more spermatozoa, supports the suggestion that boars used for artificial insemination purposes may have a far greater potential than is being utilized at present.

\section{ACKNOWLEDGMENTS}

Data presented are taken from a dissertation presented by the senior author in partial fulfilment of the requirements for the Ph.D. degree, University of Maryland.

\section{REFERENCES}

Bartlett, G. R. (1959) Phosphorus assay in column chromatography. 7. biol. Chem. 234, 466.

Dawson, R. M. C., Hemington, N. \& Lindsay, D. B. (1960) The phospholipids of the erythrocyte 'ghosts' of various species. Biochem. 7. 77, 226.

DeBohner, L. S., Soto, E. F. \& DeCohan, T. (1965) Quantitative analysis of phospholipids by thinlayer chromatography. F. Chromat. 17, 513.

DeGier, J. \& VAN DeENEN, L. L. M. (1961) Some lipid characteristics of red cell membranes of various animal species. Biochim. biophys. Acta, 49, 286.

Folch, J., Lees, M. \& Sloane-Stanley, G. H. (1957) A simple method for the isolation and purification of total lipids from animal tissues. 7. biol. Chem. 226, 497.

Gerrits, R. J., Graham, E. F. \& Cole, G. L. (1962) Effect of collection interval on the characteristics of the ejaculate in the boar. (Abstract). F. Anim. Sci. 21, 1022.

GrAY, G. M. (1960) The presence of lecithin in whole ram semen. Biochem. 7. 74, 1P.

Grogan, D. E., Mayer, D. T. \& Sikzs, J. D. (1966) Quantitative differences in phospholipids of ejaculated spermatozoa from three levels of the epididymis of the boar. F. Reprod. Fert. 12, 431.

Hartree, E. F. \& ManN, T. (1959) Plasmalogen in ram semen and its role in sperm metabolism. Biochem. 7. 71, 423.

Hartree, E. F. \& ManN, T. (1960) Phospholipids in mammalian semen. F. Reprod. Fert. 1, 23.

Hartree, E. F. \& ManN, T. (1961) Phospholipids in ram semen: metabolism of plasmalogen and fatty acid. Biochem. F. 80, 464.

Kaplan, F. (1966) The effect of daily semen collection on the boar ejaculate. Sb. čsl. Akad. zeméd. Ved, Rada E 11, 787. (Anim. Breed. Abstr. 35, 294).

Komarex, R. J., Picketr, B. W., Gibson, E. W. \& Jensen, R. G. (1965) Lipids of porcine spermatozoa, seminal plasma and gel. 7. Reprod. Fert. 9, 131.

Komarex, R. J., Pickett, B. W., Lanz, R. N. \& Jensen, R. G. (1964) Lipid composition of bovine spermatozoa and seminal plasma. F. Dairy Sci. 47, 531 .

Lovern, J. A., Olley, J., Hartree, E. F. \& Mann, T. (1957) The lipids of ram spermatozoa. Biochem. F. 67, 630 .

ManN, T. (1964) The biochemistry of semen and of the male reproductive tract. Wiley, New York.

$\mathbf{D}^{*}$ 
MaKenzie, F. F., Miller, J. G. \& Baugness, L. C. (1938) Reproductive organs and semen of the boar. Bull. Mo. agric. Exp. Stn, 279.

Mitler, L. D. \& MAYER, D. T. (1965) Lipid classes of bovine spermatozoa. F. Dairy Sci. 48, 395.

Pickett, B. W., Komarex, R. J., Gebauer, R. W. \& Grbson, E. W. (1967) Lipid and dry weight of ejaculated, epididymal and post-castrate semen from boars. F. Anim. Sci. 26, 792.

Pursel, V. G. \& Graham, E. F. (1967) Phospholipids of bovine spermatozoa and seminal plasma. $\mathcal{F}$. Reprod. Fert. 14, 203.

Quinn, P. J. \& Whrte, I. G. (1967) Phospholipid and cholesterol content of epididymal and ejaculated ram spermatozoa and seminal plasma in relation to cold shock. Aust. F. biol. Sci. 20, 1205.

Radrord, P. (1961) Factors influencing the properties of boar semen. Vet. Rec. 73, 798.

SkmMORE, W. D. \& ENTEnMan, C. (1962) Two-dimensional thin-layer chromatography of rat liver phosphatides. F. Lipid Res. 3, 47.

Skipski, V. P., Petrrson, R. F. \& Barclay, M. (1964) Quantitative analysis of phospholipids by thinlayer chromatography. Biochem. 7. 90, 374. 